\title{
Assessing Quranic Reading Proficiency in the j-QAF Programme
}

\author{
Muhammad Mustaqim Mohd Zarif ${ }^{1}$, Nurfadilah Mohamad ${ }^{1} \&$ Bhasah Abu Bakar ${ }^{2}$ \\ ${ }^{1}$ Faculty of Quranic and Sunnah Studies, Universiti Sains Islam Malaysia (USIM), Bandar Baru Nilai, Negeri \\ Sembilan, Malaysia \\ ${ }^{2}$ Islamic Education Programme, Faculty of Major Language Studies, Universiti Sains Islam Malaysia (USIM), \\ Bandar Baru Nilai, Negeri Sembilan, Malaysia \\ Correspondence: Muhammad Mustaqim Mohd Zarif, Faculty of Quranic and Sunnah Studies, Universiti Sains \\ Islam Malaysia (USIM), Bandar Baru Nilai, 71800 Nilai, Negeri Sembilan, Malaysia. Tel: 606-798-6757. E-mail: \\ mustaqim@usim.edu.my
}

Received: February 8, 2014 Accepted: April 11, 2014 Online Published: May 20, 2014

doi:10.5539/ies.v7n6p1

URL: http://dx.doi.org/10.5539/ies.v7n6p1

\begin{abstract}
In its effort to provide solid religious foundation for Muslim students, the Ministry of Education Malaysia has launched a national religious literacy initiative known as the j-QAF Programme in 2004. This programme has since been implemented in public primary schools throughout the country and incorporated as a part of the curriculum of studies. The programme includes a wide range of basic religious skills including recitation of the Quran, the learning of the Jawi script and Arabic language as well as the basics of worship. After several years of its implementation, much concern is raised on the effectiveness of this programme in achieving its objectives. Thus, this preliminary paper aims to shed some light on this matter. Specifically, it focuses on analyzing the aspect of Quranic recitation skill, which constitutes one of the core subjects of the programme. A Quran reading test was administered to selected respondents in one of the schools, and the results were analyzed through descriptive statistical methods. The findings indicate the level of proficiency of the students in mastering the skill of Quranic recitation and its possible implication and reflection on the overall effectiveness of the programme.
\end{abstract}

Keywords: j-qaf programme, Quran, primary school, Malaysia, religious literacy

\section{Introduction}

Islamic education is one of the core subjects taught at the primary and secondary schools in Malaysia. Its implementation in the national educational system is based on the Education Act 1996, section 50 (1)\&(2) that specifies the obligation of any educational establishment in the country that has at least five Muslim students to offer Islamic religious subject for a learning period of at least two hours a week. Yet for most of the non-Arab students, although learning the Quran signifies an important aspect of education, it is also a tough and challenging one. Unfamiliarity with the Arabic language in terms of its pronunciation, definite and intricate reading signs is some of the main issues hampering the mastery of Quranic recitation amongst them. In overcoming the shortcomings of the existing curriculum, the Ministry of Education Malaysia has introduced educational and curriculum reforms to improve the standard and effectiveness of Islamic education at the primary and secondary public schools. These included the introduction of the New Curriculum for the Primary Schools (Kurikulum Baru Sekolah Rendah) or KBSR in 1983 and followed by the New Curriculum for the Secondary Schools (Kurikulum Baru Sekolah Menengah) or KBSM in 1989. In these reformed curriculums, there were some improvements made to the religious subject. Yet, there were issues raised against its effectiveness several years after its implementation (Harun, 1996).

In its response, the Ministry of Education Malaysia proposed a new initiative known as the j-QAF Programme in 2004, which was announced by the then Prime Minister, Abdullah Ahmad Badawi. Yet, the real implementation of the programme in schools only started from 2005 onwards. In general, the programme functions as a supplement to the existing school curriculum. It focuses on strengthening the students' holistic understanding of the areas and topics studied in the religious subject that consists of a wide range of basic religious skills including recitation of the Quran, the learning of the Jawi (Malay-Arabic) script and Arabic language as well as the basics of worship. Specifically, it aims to produce Muslim students who are able to read and write the Jawi script skilfully; complete the reading of the whole of the Quran with proficiency; master the basics of 
communicative Arabic; and understand as well as practice the basic acts of worship (Ministry of Education Malaysia [MoE], 2004). All Muslim students enrolled in public schools at the primary level are obliged to follow the programme throughout their primary school study period, which is from Primary One right until its completion in Primary Six.

To ensure its smooth implementation, the Ministry has also prepared a specific curriculum for the j-QAF Programme together with a set of teaching modules and models. Altogether there are five teaching models that have been implemented since 2005, which are: the Jawi Writing Improvement Model, Communicative Arabic Model, Smart Prayer Model, Six-Month Completion of Quranic Recitation Model, and Rote Reading of the Quran (Tasmi ${ }^{-}$) Model. Out of these, the last two teaching models are exclusively aimed at enhancing the skill of the students in reading the Quran and ensuring their ability to complete its recitation during their study period. The basic learning materials and teaching aids are also provided by the Ministry, including the policy handbook on the implementation and management of the j-QAF curriculum, teaching models and co-curricular activities, textbooks, learning software, j-QAF learning laboratory, and others (MoE, 2006).

In many ways, the $\mathrm{j}$-QAF programme is incorporated into the mainstream educational system with minimal adjustments to the overall curriculum at the primary school level. Only the Islamic education subject was revised substantively to accommodate it, especially in terms of scheduling and distribution of teaching topics. For instance, the Six-Month Completion of Quranic Recitation Model is implemented using as many as four teaching times allocated to the Islamic education subject for the first six months of the academic year. Only in the second half of the year that more time is allotted for Islamic Education to complete its syllabus. The Ministry has specified that the Quranic recitation method employed in the session must be based on the traditional face-to-face reading method, which ideally should be conducted individually for each student. Yet due to the constraints faced, the "follow the reading of the teacher" method is employed in its place and the students need only to repeat collectively what the teacher has read.

As for the Rote Reading of the Quran (Tasmi ${ }^{\text {) }}$ Model, it is implemented outside the official school hours, usually taking about an hour in the afternoon once a week. In reality, the rote reading sessions are very challenging to be implemented effectively. Similarly, the face-to-face individual reading method employed requires a small group of students and sufficient time for individual attention. Yet, due to the large classroom size, limited number of teachers and learning sessions, only a few students can take turn and check their reading with the teacher in each session.

Other teaching models are also distributed to fit into the existing schedule with the exception of the Smart Prayer Model, which is implemented as a co-curricular activity. Furthermore, in strengthening the students' appreciation of the subject matter learnt, other programmes are also organized periodically, such as weekly group reading of a certain chapter of the Quran and especially during the month of Ramadan, as well as an annual j-QAF Festival. The peak event that marks the completion of reading the whole of the Quran and symbolizes the achievement of the programme also takes place annually on a larger scale at the school, district, state or national levels with cooperation from the schools, Ministry of Education and the surrounding communities.

Despite this, the actual implementation of the j-QAF Programme was carried out nationwide in stages due to the constraints faced by the Government on the recruitment of skilled teachers and the training of existing teaching staff. Specially appointed j-QAF teachers are sent to schools to implement the programme and assist the existing Islamic Education teachers. However, the job scope of both teachers is somewhat blurred along the line, as it is not uncommon for the j-QAF teacher to also teach Islamic Education, and vice versa.

In monitoring the progress of the students in the j-QAF Programme, the Ministry of Education has outlined a set of criteria and methods of normative and formative assessments that should be followed by the teachers. These include written and oral evaluation in the form of examination, reading test, as well as practical demonstration of certain acquired skills. All these aim towards nurturing the students for continuous development and progress throughout their learning period. The Ministry also monitors the reports sent by schools periodically to identify any possible problems and issues that need to be addressed.

Regardless, in the aspect of Quranic literacy, it is found that the assessment criteria of reporting do not address the core issue of reading proficiency. Despite having some emphasis on the Quranic reading skill of the students, the whole programme is geared towards ensuring that they complete their recitation of the whole of the Quran, at least once, during the period of the programme through collective repetition of the verses with the teacher.

Although the issue of Quranic proficiency among students have received considerable attention among researchers such as Mohd-Hani (2000), Che-Noh (2004), and Mohd (2005), yet these are mostly conducted based on the old curriculum of Islamic education prior to the introduction of the j-QAF Programme. More recent 
studies, however, tend to focus more on issues relating to Islamic education in general. In a study by Lubis et al. (2010), the focus is on the effectiveness of the strategies and techniques employed in the teaching and learning of Islamic education, which also includes the study of the Quran. In fact, development of software or computer assisted programmes for teaching and learning the Quran have also been proposed from the perspectives of computer and electronic engineering. More notably among these is the attempt by Razaly et al. (2010) to develop a Braille display prototype for the visually impaired in learning the Quran. In a similar manner, Mohamed-Elhadj (2010) has also proposed a special computer-assisted programme that can facilitate the teaching and learning of the Quran in a more effective and attractive manner.

With regard to the j-QAF Programme in particular, so far there is not much study that has been done on it. Apart from a general survey of the j-QAF Programme and its position in the national agenda of Islamic education (Zain, Mujani, \& Bakar, 2012), there are, nonetheless, a number of studies by Lubis et al. (2012, 2013), Muhamad, Wan-Ahmad, and Che-Mat (2013), Razak et al. (2008) and others that attempted to highlight certain aspects of the programme or propose some technology-based solutions to facilitate its implementation. Yet, the important issue of the effectiveness of the programme has not been addressed. It is of importance to note that the concerns voiced by those involved in the implementation and monitoring of the program have led to the organization of a first national conference on the j-QAF Programme from 19 to 20 June 2013 held in the state of Selangor, Malaysia. From the papers presented, only a few are related to the Quran. Despite the discussions on the teaching strategies, techniques and the use of technology in teaching and learning the Quran, some studies such as Arbain and Jemali (2013) have attempted to analyze its achievements in a somewhat limited manner.

It is in the light of this scenario that this paper attempts to address this issue. Specifically, it aims to assess the students' proficiency at reading the Quran through the j-QAF Programme in terms of (i) fluency of reading, (ii) adherence to the rules of tajwid, (iii) correct pronunciation of the Arabic letters, and (iv) accuracy in recognizing the reading signs. In other words, the study intends to assess the extent of the students' proficiency in reading the Quran correctly and fluently through the j-QAF Programme. Despite its preliminary nature, this study is notably significant compared with those previously mentioned in at least two aspects. Firstly, it employs an individual Quranic reading test to assess the students' ability to read the Quran, and does not simply depend on the reports prepared by the school on their achievement. Secondly, it is based on a sample of students who have successfully followed the j-QAF Programme throughout their study period in a public primary school. The ex-post facto study conducted is more realistic and reflective of the students' achievement in comparison with other studies such as Arbain and Jemali (2013), which focused on students who are still halfway through the programme. As such, it is possible from the findings obtained in this study to highlight the level of the Quranic reading proficiency among students who followed the j-QAF Programme, which could also be indicative, albeit preliminarily, and imply on the effectiveness of the programme in general.

\section{Method}

In this study, the data were collected through a Quran reading test administered to the selected samples. The results obtained were then analyzed quantitatively using descriptive statistical methods to indicate the level of the students' ability and proficiency in reading the Quran. The details of the methods used are as follows:

\subsection{Respondents}

This study involved 136 respondents (66 males and 70 females) selected randomly from a public primary school in the state of Malacca, Malaysia. The respondents represent the first cohort of Primary Six students who have successfully completed the j-QAF Programme since its implementation at the school in 2006. All respondents were Malay Muslims of the same age (12 years old), consisting of both genders with heterogeneous ability, and have learned to read the Quran through the j-QAF Programme during their primary level of education.

\subsection{Test Materials}

The reading test instrument devised for this study is based on the guidelines and objectives set by the j-QAF Programme. There are four areas of Quranic reading proficiencies assessed by the test that carry a total of 100 marks, which include fluency in reading (40 marks), correct reading of the Quran according to the rules of tajwid (40 marks), accurate pronunciation of the Arabic letters (10 marks), and recognition of the reading signs (10 marks). The reliability of the instrument used for the study of the four aspects of Quranic reading proficiencies has Cronbach's alpha coefficient at 0.88 . Each of the respondents was asked to read three randomly selected verses from chapters al-Baqarah: 126, al-Isra': 80-81, and Nuh: 27-28 of the Quran, and marks were given in the scoring form based on their performance and quality of reading. These verses were chosen due to its content of the four aspects of reading proficiencies assessed in the test. The scores of the respondents were then categorized based on their proficiency into good, average and weak. 


\subsection{Test Procedures}

The study was implemented in two phases; (i) pilot study, and (ii) conducting the actual Quran reading test to the respondents. In undertaking the test, permissions from the relevant authorities were obtained, including the Educational Planning and Research Division, Ministry of Education Malaysia, the Education Department of the State of Malacca, the relevant District Education Office and the school. The anonymity of the respondents who participated in the test is maintained at all times.

\subsubsection{Phase 1: Pilot Study}

In this phase, the reading test instrument was devised from the assessment criteria and guidelines set for use in the j-QAF Programme (MoE, 2005). There are four areas of Quranic reading proficiencies involved, which include fluency in reading, correct reading of the Quran according to the rules of tajwid, accurate pronunciation of the Arabic letters, and recognition of the reading signs. The method of recording the marks of the reading of each type of proficiency tested is based on the criteria used by the National Quranic Recitation Council (JAKIM, 2009) with some adjustments. This is to avoid confusion in the marking and to ensure that each type of proficiency is properly assessed. The pilot test was conducted on ten randomly selected Primary Six students from the school. The teachers involved in the teaching of the Quran through the j-QAF Programme at the school were also consulted on the appropriateness and clarity of the test and its marking scheme. Based on the feedbacks given, the reading test instrument was further structured and improved.

\subsubsection{Phase 2: The Actual Study}

136 students were administered the Quran reading test individually in a classroom setting. Each respondent was given a unique identifier to ensure the person's anonymity, and was shown and asked to recite the three predetermined verses of the Quran (al-Baqarah: 126, al-Isra': 80-81, and Nuh: 27-28). The readings of the respondents were recorded using an electronic voice recorder for later analysis. The recorded readings were evaluated, assessed and rated by an expert and experienced reciter of the Quran in the mark sheets provided. The expert had to listen to the reading of each respondent for four times to assess the four aspects of Quranic reading proficiencies covered in the test. The reading test took about 20 days to be implemented to all specified respondents.

\subsection{Data Analysis}

The data acquired from the reading test were analyzed quantitatively using the descriptive statistical methods and presented in the forms of mean, standard deviation, frequency and percentage. The overall score obtained by each respondent is classified into good (A), average (B) and weak (C). In the overall score of 100 marks, 70 to 100 marks are considered as grade A, while 34 to 69 marks fall under grade B and 1 to 33 points are in grade C. As for each aspect of the reading proficiency, the classification is as follows: For the aspects that carry 40 marks each, grade A would be in the 28 to 40 marks range, grade B is 14 to 27 marks, and grade C is 1 to 13 marks range. Whereas for the aspects that carry 10 marks each, grade A is 8 to 10 marks, grade B is 4 to 7 marks, while grade $C$ is 1 to 3 marks. According to Nasir (2005), this grading is determined based on the arbitrary value. From this classification, the level of Quranic reading proficiency is described according to the grades as follows: Grade A means that the respondent is able to read the Quran fluently, with correct pronunciation and recognition of the reading signs while adhering to the rules of tajwid, while grade $\mathrm{B}$ means that the respondent is able to read with moderate fluency but not able to adhere to the rules of tajwid. On the other hand, grade $\mathrm{C}$ means that the respondent is not able to recite the Quran and adhere completely to the rules of tajwid.

\section{Results and Discussion}

\subsection{Fluency of Reading}

The first question addressed by this study was to determine the respondents' proficiency level of Quranic reading fluency through the j-QAF programme. The mean score of the fluency aspect of this sample was 25.63 and standard deviation of 12.883 (Table 4). Table 1 shows that $64 \%$ of the respondents obtained Grade A with the highest score of 28 to 40 marks. On the other hand, $8.1 \%$ of the respondents obtained Grade B, while $27.9 \%$ obtained Grade $\mathrm{C}$ with scores between 1 to 13 marks. The finding also indicates a significant contribution of fluency to the mastery of Quranic reading $(\beta=.368, \mathrm{p}<0.001)$. From Table 2 , it can be seen that females (mean $=26.90$, std. $\mathrm{dev}=12.468)$ performed better than males $($ mean $=24.29$, std. dev $=13.272)$ in terms of fluency of reading. However, $\mathrm{t}$-test conducted indicates that the difference is not significant statistically $\mathrm{t}_{(134)}=-1.183, \mathrm{p}>$ 0.05. It also indicates that there is no correlation between fluency and gender. 


\subsection{Adherence to the Rules of Tajwid}

The results of the Quranic reading proficiency test from the aspect of adherence to the rules of tajwid are similarly divided into three levels: A (good), B (average), and C (weak). The tajwid rules that were tested included the nun sakinah, mim sakinah, tanwin, madd, nun tashdid, mim tashdid, alif lam shamsiyyah, alif lam qamariyyah, and qalqalah. Scoring for adhering to the rules of tajwid was based upon mistakes made by the respondents where one mark was deducted for every mistake made. The overall mean score obtained was 23.44 with a 12.08 standard deviation (Table 4). The rules of tajwid tested are those covered by the learning syllabus of the j-QAF Programme. The finding also indicates a significant contribution of tajwid to the mastery of Quranic reading $(\beta=.256, \mathrm{p}<0.001)$. Table 2 shows that females (mean $=24.71$, std. dev $=11.712)$ performed better than males (mean $=22.09$, std. $\mathrm{dev}=12.409)$ in applying the rules of tajwid when reciting the Quran, however, the difference is not statistically significant $t_{(134)}=-1.268, p>0.05$. It also indicates that there is no correlation between adherence to the rules of tajwid and gender.

\subsection{Accurate Pronunciation of Arabic Letters}

The results of the Quranic reading proficiency test from the aspect of accurate pronunciation of Arabic letters are categorised into three levels: A (good), B (average), and C (weak). The assessment of pronunciation was based on five groups of Arabic huruf (letters). Marks were based on the correct pronunciation of each letter and were deducted if the respondents cannot articulate the pronunciation fluently or accurately. Table 1 shows that $45.6 \%$ of the respondents have successfully obtained Grade A with a score ranging from 8 to 10 marks. Another $25 \%$ of the respondents obtained Grade B, whose marks range from 4 to 7 , while $29.4 \%$ of the respondents obtained Grade $\mathrm{C}$ whose scores range from 1 to 3 marks. The overall mean score obtained by the sample of study was 6.03 with a standard deviation of 3.20 (Table 4). The finding also indicates a significant contribution of accurate pronunciation of Arabic letters to the mastery of Quranic reading $(\beta=.181, \mathrm{p}<0.001)$. Females (mean $=6.27$, std. $\mathrm{dev}=3.059)$ performed better than males (mean $=5.77$, std. $\mathrm{dev}=3.355)$ in this aspect (Table 2). Here again, the difference is not statistically significant $t_{(134)}=-.907, p>0.05$. It also indicates that there is no relationship between accurate pronunciation of Arabic letters and gender.

\subsection{Recognition of the Reading Signs}

The results of the Quranic reading proficiency test from the aspect of recognition of the reading signs are also categorised into three levels: A (good), B (average), and C (weak). The punctuation marks assessed in this test were the recognition of the signs of fathah, dammah, kasrah, sukun, shiddah, and tanwin. One mark was deducted if a mistake was made in reading the punctuation signs. The overall mean score obtained was 6.07 with a 3.26 standard deviation (Table 4). Table 1 shows that $47.8 \%$ of the respondents have successfully obtained Grade A with scores ranging from 8 to 10 marks. More than 20\% of the respondents obtained Grade B, whose marks range from 4 to 7 , while $30.9 \%$ of the respondents obtained Grade $\mathrm{C}$. The finding also indicates a significant contribution of recognition of the reading signs to the mastery of Quranic reading $(\beta=.214, p<$ $0.001)$. Females $($ mean $=6.37$, std. dev $=3.16)$ performed better than males (mean $=5.76$, std. dev $=3.347)$ in punctuation. However, the difference is not statistically significant $t_{(134)}=-1.099, p>0.05$. It also indicates that there is no correlation between punctuation and gender.

Table 1. Respondents' performances on the four aspects of Quranic reading proficiency

\begin{tabular}{|c|c|c|c|c|c|c|c|c|c|c|}
\hline & & \multicolumn{2}{|c|}{ Fluency } & \multicolumn{3}{|c|}{ Rules of Tajwid } & \multicolumn{2}{|c|}{ Pronunciation } & \multicolumn{2}{|c|}{ Reading Signs } \\
\hline & & $\mathrm{N}$ & $\%$ & $\mathrm{~N}$ & $\%$ & & $\mathrm{~N}$ & $\%$ & $\mathrm{~N}$ & $\%$ \\
\hline \multicolumn{11}{|l|}{ Grade } \\
\hline $\mathbf{A}$ & & 87 & 64.0 & 71 & 52.2 & & 62 & 45.6 & 65 & 47.8 \\
\hline B & & 11 & 8.1 & 24 & 17.6 & & 34 & 25.0 & 29 & 21.3 \\
\hline $\mathbf{C}$ & & 38 & 27.9 & 41 & 30.1 & & 40 & 29.4 & 42 & 30.9 \\
\hline $\boldsymbol{\beta}$ & & & .368 & & .256 & & & .181 & & .214 \\
\hline $\begin{array}{l}\text { Gender } \\
\text { Grade }\end{array}$ & with & $\begin{array}{l}\chi_{(\mathrm{df}=2)}^{2} \\
=.183\end{array}$ & $=3.393, \mathrm{p}$ & $\begin{array}{l}\chi_{(\mathrm{df}=2)}^{2} \\
=.296\end{array}$ & $=2.436$ & $\mathrm{p}$ & $\begin{array}{l}\chi_{(\mathrm{df}=2)}^{2} \\
=.163\end{array}$ & $=3.626, \quad \mathrm{p}$ & $\begin{array}{l}\chi_{(\mathrm{df}=2)}^{2} \\
=.277\end{array}$ & $=2.570, \mathrm{p}$ \\
\hline
\end{tabular}


Table 2. Quranic reading performances based on gender

\begin{tabular}{cccccccc}
\hline Construct & Gender & $\mathrm{N}$ & Mean & Std.dev. & $\mathrm{df}$ & $\mathrm{t}$ & Sig. (2-tailed) \\
\hline Fluency & Male & 66 & 24.29 & 13.272 & 134 & -1.183 & 0.239 \\
& Female & 70 & 26.90 & 12.468 & & & \\
Rules of Tajwid & Male & 66 & 22.09 & 12.409 & 134 & -1.268 & 0.207 \\
& Female & 70 & 24.71 & 11.712 & & & \\
Pronunciation & Male & 66 & 5.77 & 3.355 & 134 & -0.907 & 0.366 \\
& Female & 70 & 6.27 & 3.059 & & & \\
Reading Signs & Male & 66 & 5.76 & 3.347 & 134 & -1.099 & 0.274 \\
& Female & 70 & 6.37 & 3.168 & & & \\
\hline
\end{tabular}

\subsection{Correlation among the Various Aspects of Quranic Reading Proficiency}

Inter-sub-constructs correlations are given in Table 3. The purpose was to identify the correlation of the various aspects of Quranic reading proficiency, which are made up of: (i) fluency of reading, (ii) adherence to the rules of tajwid, (iii) accurate pronunciation of Arabic letters, and (iv) recognition of the reading signs. There is a high correlation between each of the components of the Quranic reading proficiency. Fluency of reading has a very strong correlation with the rules of tajwid having $\mathrm{r}=.981$ and it is very significant statistically at $\mathrm{p}<0.01$. Fluency of reading also has a strong correlation with accurate pronunciation of Arabic letters $(r=.960, p<0.01)$ and with recognition of the reading signs $(\mathrm{r}=.962, \mathrm{p}<0.01)$.

Table 3. Inter-correlation amongst sub-constructs of Quranic reading proficiency

\begin{tabular}{lcccc}
\hline \multicolumn{1}{c}{ Construct } & Fluency & Rules of Tajwid & Pronunciation & Reading Signs \\
\hline Fluency & 1 & $.981^{* *}$ & $.960^{* *}$ & $.962^{* *}$ \\
Rules of Tajwid & & 1 & $.966^{* *}$ & $.963^{* *}$ \\
Pronunciation & & & 1 & $.956^{* *}$ \\
Reading Signs & & & & 1 \\
\hline
\end{tabular}

** Correlation is significant at the 0.01 level (2-tailed)

\subsection{Overall Performance of Quranic Reading Proficiency}

Table 4 shows that the overall level of Quranic reading proficiency among respondents stays at the above average level with the mean score of 61.18 . The fluency aspect has the highest mean at $25.63(0.437$ standardisation) and the aspect of the rules of tajwid has the lowest mean at 23.44 (0.285 standardisation). This means that the students are more proficient in the aspect of fluency compared with the aspect concerning the rules of tajwid. The second highest aspect after fluency is reading signs (0.328 standardisation) with a mean value of 6.07 and the third highest is the aspect of pronunciation ( 0.322 standardisation) with the mean value of 6.03. From all the four aspects, it is found that the overall aspects of the respondents' Quranic reading proficiency are at the average level. This means that although the respondents can read the Quran, yet they had some difficulties in the four aspects of reading proficiency especially concerning the rules of tajwid. In fact, this finding corroborates with the information from the j-QAF teachers at the school who pointed out that the level of Quranic reading proficiency of students in this school as a whole was at the average level and that the mastery of the rules of tajwid posed some problems to them. 
Table 4. Level of Quranic reading proficiency

\begin{tabular}{lccc}
\hline Construct & Mean Score & Total Marks & Std.dev. \\
\hline Fluency & 25.63 & 40 & 12.883 \\
Rules of Tajwid & 23.44 & 40 & 12.08 \\
Pronunciation & 6.03 & 10 & 3.20 \\
Reading Signs & 6.07 & 10 & 3.26 \\
Overall Mean & 61.18 & 100 & 31.13 \\
\hline
\end{tabular}

It is very interesting to note here the persistence of the mediocre level of Quranic reading proficiency of students despite the various efforts and initiatives implemented by the Ministry of Education. In a way, the findings of the preliminary study undertaken here suggest almost a similar trend shown in the previous studies by Che-Noh (2004), Mat-Salleh (2003), Satar (2001), Mohd-Nooh (2000) and Mohd-Hani (2000) on the average proficiency level of Quranic reading amongst school children despite the introduction of a more structured national initiative through the j-QAF Programme. Undoubtedly, a more comprehensive study of national magnitude needs to be undertaken to assess the overall effectiveness and achievement of the programme. Nevertheless, despite the limited nature of the test conducted here, it indicates the importance of proper implementation of this national agenda and the responsibilities that should be shouldered by the ministry, schools, teachers, parents and students alike in its realization.

Appropriate measures should also be taken to improve the Quranic reading proficiency of students with average and weak reading skills, especially in the aspect of the mastery of the rules of tajwid and fluency. Practically, the once a week Quran reading session should be increased to allocate for a more individual face-to-face time for the students with the teacher. In a similar manner, the syllabus of studies should also be adjusted to suit the needs of students with various learning abilities. More importantly, the assessment method used in the programme should be geared towards improving the Quranic reading skill of the students rather than aiming for the completion of reading the Quran collectively throughout their study period. In short, continuous evaluation and improvement by the relevant parties involved in the implementation of the programme is crucial to realise its main objective of producing Quran-literate generations of school children in Malaysia.

\section{References}

Arbain, P., \& Jemali, M. (2013). Pencapaian tilawah al-Quran program j-QAF di Perak: Satu tinjauan awal (Achievement of students in reading the Quran through the j-QAF programme in Perak: A preliminary survey). Paper presented at the National Research Seminar on j-QAF 2013 (SKP j-QAF 2013)-Proceedings, 321-328.

Che-Noh, M. A. (2004). Celik al-Quran di kalangan pelajar tingkatan satu zon Pudu Kuala Lumpur (Quranic literacy amongst secondary one students in the Pudu zone of Kuala Lumpur). Unpublished research report. Bangi: National University of Malaysia.

Department of Islamic Development Malaysia (JAKIM). (2009). Guidelines on the national al-Quran recital assembly (Amended) 2009. National al-Quran Recital Assembly official website. Retrieved from http://www.tilawah.gov.my/index.php/ms/info-tilawah/syarat-syarat-penyertaan

Harun, A. B. (1996). Pengajian al-Quran dalam program KBSM (Quranic studies in the KBSM programme) (Unpublished Master's thesis, Faculty of Education, National University of Malaysia).

Laws of Malaysia. (2006). Education Act 1996 (Act 550). Kuala Lumpur: PNMB.

Lubis, M. A., Daud, Y., Sabri, R. M., Yusoff, H., \& Zakaria, E. (2012). Developing multimedia software for j-QAF year-one students specification on wuduk (ablution). International Journal of Learning, 18(6), 301-314.

Lubis, M. A., Nordin, N., Embi, M. A., Daud, M. Y., Din, R., Karim, A., \& Al-Ganzouri, F. M. (2013). Development and evaluation of a multimedia software (smart solat) for j-QAF program for Malaysian primary schools. Research Journal of Applied Sciences, 8(1), 5-8. http://dx.doi.org/10.3923/rjasci.2013.5.8

Lubis, M. A., Yunus, M. M., Ishak, N. M., Muhamad, T. A., \& Diao, M. (2010). The effectiveness of strategies and techniques in teaching and learning Islamic education. Paper presented at the International Conference on Education and Educational Technologies-Proceedings, 218-223. 
Mat-Salleh, M. N. (2003). Pencapaian tilawah al-Quran melalui kaedah Iqra' di sekolah-sekolah rendah kebangsaan daerah Setiu, Terengganu (The achievement of primary school children in reading the Quran through the Iqra' method in the district of Setiu, Terengganu) (Unpublished Master's thesis, National University of Malaysia).

Ministry of Education Malaysia (MoE). (2004).j-QAF: Panduan pelaksanaan model dan modul pengajaran dan pembelajaran (j-QAF: Guidelines on the implementation of the teaching and learning models and modules). Kuala Lumpur: Department of Islamic and Moral Education.

Ministry of Education Malaysia (MoE). (2005). Format pentaksiran pendidikan Islam (Assessment format of Islamic education). Kuala Lumpur: Examination Board, Ministry of Education.

Ministry of Education Malaysia (MoE). (2006). Buku panduan dasar, pelaksanaan dan pengurusan kurikulum $j$-QAF (Guidelines on the policy, implementation and management of the j-QAF curriculum). Kuala Lumpur: Department of Islamic and Moral Education.

Mohamed-Elhadj, Y. O. (2010). E-halagat: An e-learning system for teaching the holy Quran. Turkish Online Journal of Educational Technology, 9(1), 54-61.

Mohd, I. (2005). Kaedah pembelajaran al-Quran (The methods of learning the Quran). Jakarta: Gunung Agung.

Mohd-Hani, F. (2000). Kemahiran membaca nun sakinah di kalangan pelajar tingkatan 3 di sebuah sekolah menengah di daerah Petaling (The proficiency of reading nun sakinah amongst secondary 3 students in a high school in the district of Petaling). Unpublished research report. Kuala Lumpur: Faculty of Education, University of Malaya.

Mohd-Nooh, R. (2000). Penguasaan kemahiran membaca al-Quran di kalangan pelajar tingkatan 4 Sekolah Menengah Kebangsaan Gurun Kedah Darul Aman (Mastery of Quranic reading amongst secondary 4 students at Gurun High School Kedah Darul Aman). Unpublished academic project. Bangi: Faculty of Education, National University of Malaysia.

Muhamad, I., Wan-Ahmad, W. M. A., \& Che-Mat, A. (2013). Attitudes and reality of Arabic skills proficiency in j-QAF program students (Sikap dan realiti penguasaan kemahiran bahasa Arab pelajar program j-QAF). GEMA Online Journal of Language Studies, 13(2), 81-97.

Nasir, Y. (2005). Penguasaan kemahiran membaca al-Quran menerusi Sistem Qiraati di Taman Qiraati kawasan Kajang (The mastery of Quranic reading according to the Qiraati System at Taman Qiraati, the district of Kajang) (Unpublished Master's thesis, National University of Malaysia).

Razak, Z., Ibrahim, N. J., Idris, M. Y. I., Mohd-Tamil, I., Mohd-Yusoff, M. Y., \& Abdul-Rahman, N. N. (2008). Quranic verse recitation recognition module for support in j-QAF learning: A review. IJCSNS International Journal of Computer Science and Network Security, 8(8), 207-216.

Razaly, F., Ajizan, N. H., Saad, S. M., Yaacob, M. S., Zain, M. Z. M., Hussein, M., \& Musa, A. R. (2010). User-friendly system for the visually impaired in learning al-Quran. WSEAS Transactions on Systems, 9(6), $659-668$.

Satar, M. S. (2001). Keberkesanan Kaedah Hattawiyah dalam pembelajaran tilawah al-Quran (The effectiveness of the Hattawiyah Method in learning the Quran). Unpublished academic project. Bangi: National University of Malaysia.

Zain, F. M., Mujani, W. K., \& Bakar, I. A. (2012). The Islamic education and the "j-QAF” program in Malaysia. Advances in Natural and Applied Sciences, 6(3), 310-315.

\section{Copyrights}

Copyright for this article is retained by the author(s), with first publication rights granted to the journal.

This is an open-access article distributed under the terms and conditions of the Creative Commons Attribution license (http://creativecommons.org/licenses/by/3.0/). 